\title{
PRELIMINARY STUDY ON THE FLOWERING AND FRUITING BEHAVIORS OF NYAMPLUNG (Calophyllum inophyllum Linn.)
}

\author{
Resti Wahyuni ${ }^{1}$, Cecep Handoko ${ }^{2}$, Retno Agustarini ${ }^{3}$
}

\begin{abstract}
Nyamplung (Calophyllum inophyllum Linn.) has high potential as raw material for biodiesel.Understanding reproductive growth behavior of nyamplung is important if the species want to be developed for supporting biodiesel program. This study is aiming at understanding the flowering and fruiting characteristics and their development; ripe fruit production; fruit harvesting time and seed viability of nyamplung. The study completed in 2010 in Jerowaru and Korleko (East Lombok District), and North Batukliang (Central Lombok District). The method consists of direct observation and seed germination trial. The results indicated that nyamplung has a perfect flower were both male and female reproductive organs are in a single flower. Nyamplung fruit is globose with its length from 2.5 to 3.4 and the width from 2.3 to $3.3 \mathrm{~cm}$. Nyamplung flowering period was different between sites as a respond to biophysical and agro-climatic condition of the habitat. The flowering period tends to delay with the increase of rainfall and this association had high correlation $(97,3 \%)$. The flowering period completes within a month, while the fruiting period within 1.5 to 2.5 months. The percentages of ripe fruits at each location were $40.29 \%$ (Korleko), 36.45\% (North Batukliang), and 32.78\% (Jerowaru). The percentages of germinated seeds were 94.87\% (North Batukliang), 91.01\% (Jerowaru), and 77.05\% (Korleko). Mature fruits were potentially available in August in Jerowaru and Korleko, and in October in North Batukliang.
\end{abstract}

Keywords: Calophyllum inophyllum Linn., flowering, fruiting, seed viability

\section{INTRODUCTION}

Nyamplung (Calophyllum inophyllum Linn.) is a medium to a large tree species and belongs to the family of Clusiaceae. The trees can reach up to $30 \mathrm{~m}$ height and $80 \mathrm{~cm}$ in diameter. The tree is native to Australia, South Asia and South East Asia (Friday and Okano, 2006). Habitat for the trees ranges from altitude of 0 to $200 \mathrm{~m}$ above sea level, rainfall type $\mathrm{A}$ and $\mathrm{B}$, and between 1,000-3,000 mm/year. Nyamplung is categorized as a multi-purpose tree species and has high potential as biodiesel raw material with $74 \%$ productive substance contents (Departemen Kehutanan, 2008). The trees

\footnotetext{
${ }^{1,2,3}$ Researcher in Research Institute of Non Timber Forest Product Technology resti_bio@yahoo.com, cecep_h@yahoo.com, retno.agustarini@gmail.com
}

produce flowers throughout the year although the highest fruit production occurs during August to September. Nyamplung starts to produce fruits at age of 7 years and continue fruiting up to the age of 58 years (Bustomi et al., 2008).

Despite of its wide distribution area, information on phenology (flowering and fruiting behavior) of nyamplung is still limited. The information is needed to know the optimum quantity and quality of fruits and seeds production. The study aims at knowing the flower and fruit characteristics and their development, ripe fruits production, seed viability, and fruit harvesting time. The study completed from April to October 2010 and located in Jerowaru and Korleko villages in East Lombok District and North Batukliang village in Central Lombok District. 


\section{MATERIALS AND METHODS}

\section{A. Materials}

The materials used for this study were nine nyamplung trees, three trees each from Jerowaru, Korleko and North Batukliang for flowering and fruiting observation. The seeds were harvested for germination trials. Some equipment used in the study was Geographical Positioning Systems (GPS) tool, camera, thermo-hygrometer, and microscope.

\section{B. Methods}

The trees were selected from a productive population, which have straight stem and having some branches heading to the east or west. The distance between the observed trees at each location was minimum $20 \mathrm{~m}$. Ten branches at each tree were labeled, then three flowers were selected from the labeled branches for flowering observation and continued for fruiting observation.

Flower observation was done regularly, which was started when $50 \%$ of the tree population was flowering. The observation was done by measuring flower length from the bottom to the top of the flowers. Fruiting observations were started since the initial fruit had been formed. These observations were done regularly on fruit dimension (length and width) and development (young to mature). Ripe fruit percentage was obtained by dividing the number of ripe fruits by the number of all fruits from 10 labeled branches at each tree in a certain harvesting period. Ripe fruits were germinated, and the germinated seed percentage was calculated by dividing the number of germinated seed by the number of seed used.

It was assumed that the tree flowering and fruiting process was influenced by the specific environmental condition. For that reason, biophysical characteristic and agro-climate condition of the sites were observed. The observed characteristics were temperature, monthly rainfall and altitude.

\section{Data Analysis}

Correlation between flowering period with monthly rainfall, canopy temperature, and altitude were analyzed using Pearson's correlation analyses. Variation in flower length and fruit length were analyzed using variance analyses (ANOVA) followed by Least Significant Difference (LSD) multiple comparison test at $\varrho=0.01$.

\section{RESULTS AND DISCUSSION}

\section{A. Flowering Session}

The results showed that nyamplung flowers in April to May in Jerowaru (Figure 1), May to June in Korleko (Figure 2), and June to July in North Batukliang (Figure 3). The periodicity difference on flowering was affected by the difference on habitat condition. Pallardy (2008) stated that flowering periodicity of plants in the tropics was very diverse. In non-seasonal tropical climate, the flowering of plants might be seen throughout the year with the greatest flowering occurred at a

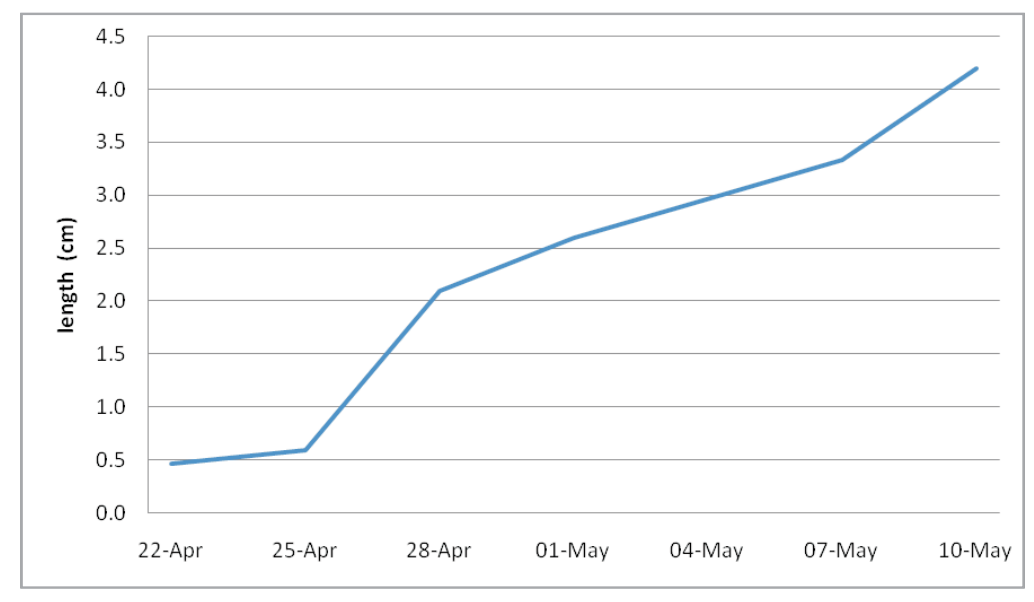

Figure 1. Nyamplung flowering season in Jerowaru 


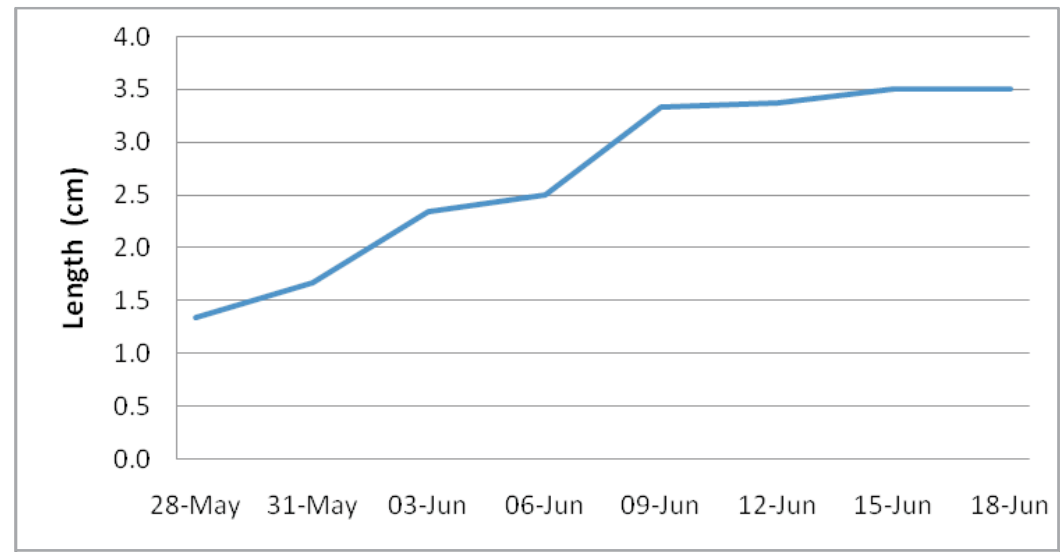

Figure 2. Nyamplung flowering season in Korleko

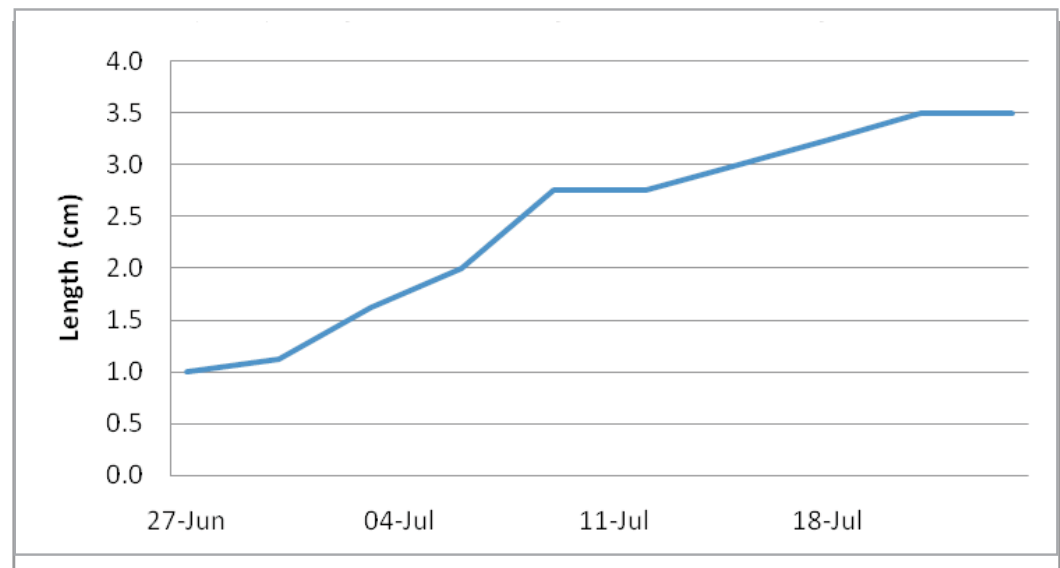

Figure 3. Nyamplung flowering season in North Batukliang

certain time of the year, and much greater when there was a distinct dry season. Lesica and Kittelson (2010) stated that in semi-arid regions, precipitation and temperature were associated with flowering phenology. In relation to the land altitude, Warnock et al. (1993) stated that the plants that grow on plateau would have late flowering session than those that grow on lowland.

In North Batukliang with altitude of $425 \mathrm{~m}$ above sea level (asl), the flowering period was occurred at temperature of $29.5^{\circ} \mathrm{C}$, and monthly rainfall of $242 \mathrm{~mm}$. In Korleko with altitude of 75 $\mathrm{m}$ asl, the flowering period was occurred at temperature of $34.2^{\circ} \mathrm{C}$, and monthly rainfall of $130 \mathrm{~mm}$. In Jerowaru with altitude of $50 \mathrm{~m}$ asl, the flowering period was occurred at temperature of $32.7^{\circ} \mathrm{C}$, and monthly rainfall of $83 \mathrm{~mm}$ (Table 1$)$.

Based on the correlation analyses (Table 2), the correlation coefficients between nyamplung flowering period with canopy temperature, monthly rainfall, and altitude were $66.7 \%, 97.3 \%$ and $89.4 \%$, respectively. The analyses indicated

Table 1. Nyamplung flowering periods, site temperatures, monthly rainfalls, and altitudes in North Batukliang, Korleko, and Jerowaru

\begin{tabular}{ccccc}
\hline Site & $\begin{array}{c}\text { Flowering } \\
\text { period (month) }\end{array}$ & $\begin{array}{c}\text { Canopy } \\
\text { Temperature } \\
\left({ }^{\circ} \mathrm{C}\right)\end{array}$ & $\begin{array}{c}\text { Monthly Rainfall } \\
(\mathrm{mm})\end{array}$ & $\begin{array}{c}\text { Altitude } \\
\text { (m asl) }\end{array}$ \\
\hline North Batukliang & Juni-Juli & 29.5 & 242 & 425 \\
Korleko & Mei-Juni & 34.2 & 130 & 75 \\
Jerowaru & April-Mei & 32.7 & 83 & 50 \\
\hline
\end{tabular}


Table 2. Results of correlation analyses between nyamplung flowering periods and canopy temperature, monthly rainfall, and altitude

\begin{tabular}{lrrrr}
\hline \multicolumn{5}{c}{ Pearson Correlation Coefficients, N =3 } \\
Prob $>$ & r & under H0: Rho $=0$ \\
\hline FP & CT & \multicolumn{1}{c}{ Alt } & \multicolumn{1}{c}{ MR } \\
\hline CT & 1.00000 & -0.66647 & 0.89429 & 0.97326 \\
& & 0.5356 & 0.2954 & 0.1476 \\
Alt & $\mathbf{0 . 6 6 6 4 7}$ & 1.00000 & -0.92963 & -0.81991 \\
& 0.5356 & & 0.2402 & 0.3880 \\
MR & $\mathbf{0 . 8 9 4 2 9}$ & -0.92963 & 1.00000 & 0.97317 \\
& 0.2954 & 0.2402 & & 0.1478 \\
& $\mathbf{0 . 9 7 3 2 6}$ & -0.81991 & 0.97317 & 1.00000 \\
\hline
\end{tabular}

\section{Notes:}

$\mathrm{N}=$ sites number

FP $=$ Flowering Period

$\mathrm{CT}=$ Means of Canopy Temperature

Alt $=$ Altitude

MR = Monthly Rainfall

Table 3. Variance analyses result of flower length between individual flowers

\begin{tabular}{lrrrrr}
\hline & \multicolumn{1}{c}{ Sum of } & & & & \\
& Squares & Df & Mean Square & F & Sig. \\
\hline Between Groups & 3.592 & 2 & 1.796 & 6.883 & $.004\left(^{*}\right)$ \\
Within Groups & 6.262 & 24 & .261 & & \\
Total & 9.854 & 26 & & & \\
\hline
\end{tabular}

*) significant at the 0.01 level

Table 4. LSD test results of flower length between individual flowers from all sites

\begin{tabular}{|c|c|c|c|c|c|c|}
\hline \multirow[t]{2}{*}{ (I) SITE } & \multirow[t]{2}{*}{ (J) SITE } & \multirow{2}{*}{$\begin{array}{c}\text { Mean } \\
\text { Difference } \\
(\mathrm{I}-\mathrm{J})\end{array}$} & \multirow{2}{*}{ Std. Error } & \multirow{2}{*}{ Sig. } & \multicolumn{2}{|c|}{$99 \%$ Confidence Interval } \\
\hline & & & & & Lower Bound & Upper Bound \\
\hline \multirow[t]{2}{*}{1.00} & 2.00 & $.8000\left(^{*}\right)$ & .24080 & .003 & .1265 & 1.4735 \\
\hline & 3.00 & $.7444\left(^{*}\right)$ & .24080 & .005 & .0709 & 1.4179 \\
\hline \multirow[t]{2}{*}{2.00} & 1.00 & $-.8000\left(^{*}\right)$ & .24080 & .003 & -1.4735 & -.1265 \\
\hline & 3.00 & -.0556 & .24080 & .819 & -.7291 & 6179 \\
\hline \multirow[t]{2}{*}{3.00} & 1.00 & $-.7444\left(^{*}\right)$ & .24080 & .005 & -1.4179 & -.0709 \\
\hline & 2.00 & .0556 & .24080 & .819 & -.6179 & .7291 \\
\hline
\end{tabular}

$\left.{ }^{*}\right)$ The mean difference is significant at the 0.01 level.

Site $1.00=$ Jerowaru; Site $2.00=$ Korleko; Site $3.00=$ North Batukliang

that the increase in monthly rainfall was highly correlated $(97.3 \%)$ with the delay on flowering period. The trees that grow in habitat with more monthly rain showed more belated flowering season than those that grow in habitat with less rain. However, more information is still required to clearly understand such relationship.
The longevity of flower was regulated by environmental condition although it was more determined by pollination. The longevity of individual flowers, usually quite short but differs depending on the species, habitat, and environmental conditions (Pallardy, 2008). Bud development was controlled by an interaction of 


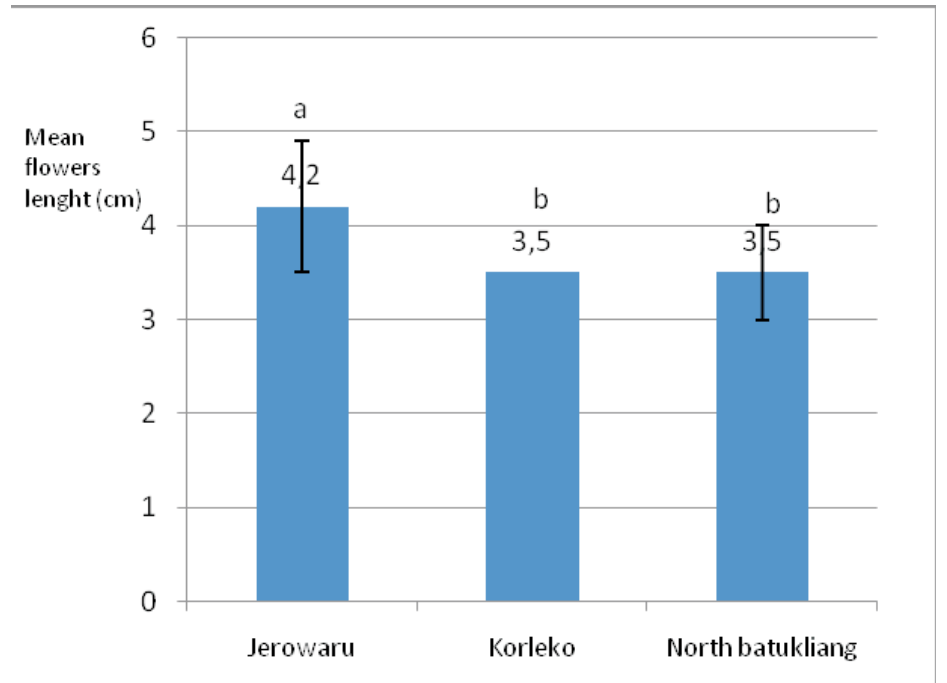

Figure 4. Nyamplung flower length. The same letters on the histograms indicate no significant difference in the corresponding flower length $(\varrho<0.01$ by LSD test)

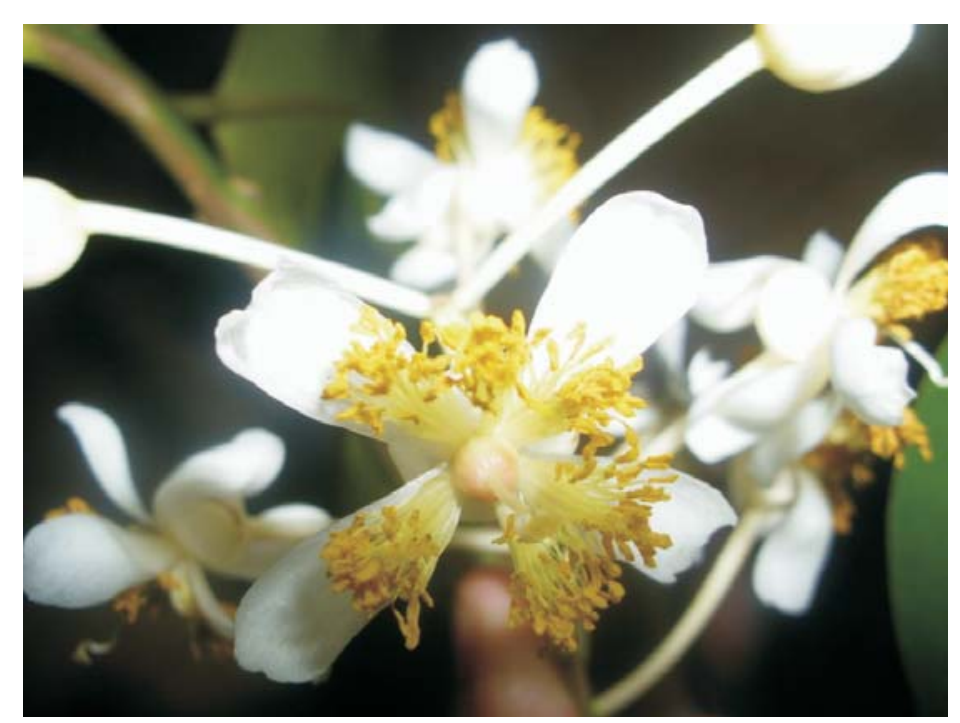

Figure 5. Nyamplung flower

environmental factors and indigenous factors. However, the relationship between environmental factors with flowering of plant is still difficult to identify (Raghavendra, 1991).

Flower longevity and bud development of the trees differ between sites. At final growth, the length of flower in the three locations ranged from 3.5 to $4.2 \mathrm{~cm}$. Analyses of variance (ANOVA) of flower length between individual flowers showed a significant flower length difference (Table 3). In line with the variance analyses, the LSD test showed different flower length between trees in different locations (Table 4.). Further analyses indicated that there were two different flower lengths; the longer sizes were produced from Jerowaru $(4.2 \mathrm{~cm})$, and the shorter sizes $(3.5 \mathrm{~cm})$ were produced from Korleko and North Batukliang (Figure 4).

Based on the observation, nyamplung flower was white, clustered, and have 4-6 oblong petals. It is similarly with Friday and Okano (2006) stated that nyamplung flower is white, clustered, and have 4-8 oblong petals. Moreover, the observation showed that the flower was perfect (Figure 5). Both male and female reproductive organs were located in a single flower. The male and female reproductive organs of nyamplung flower can be seen in Figure 6 and 7 respectively. 


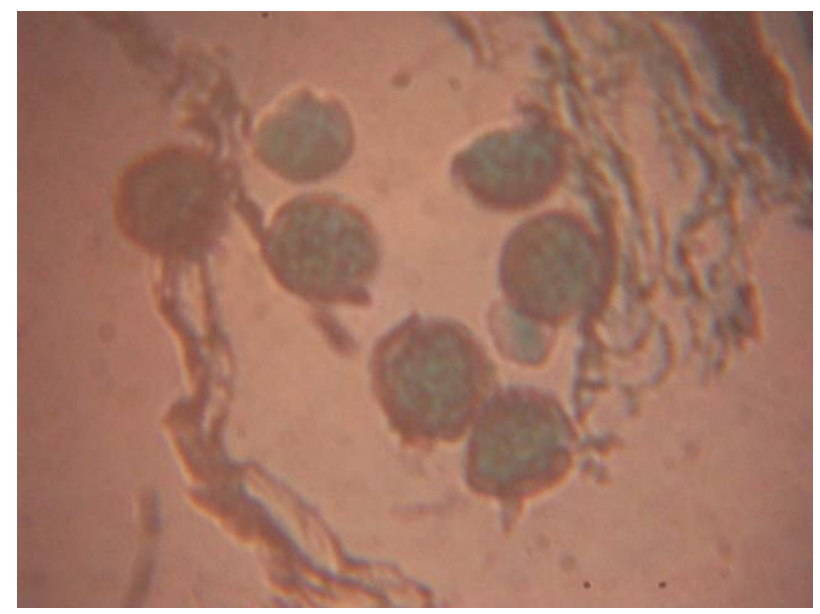

Figure 6. Nyamplung flower pollen

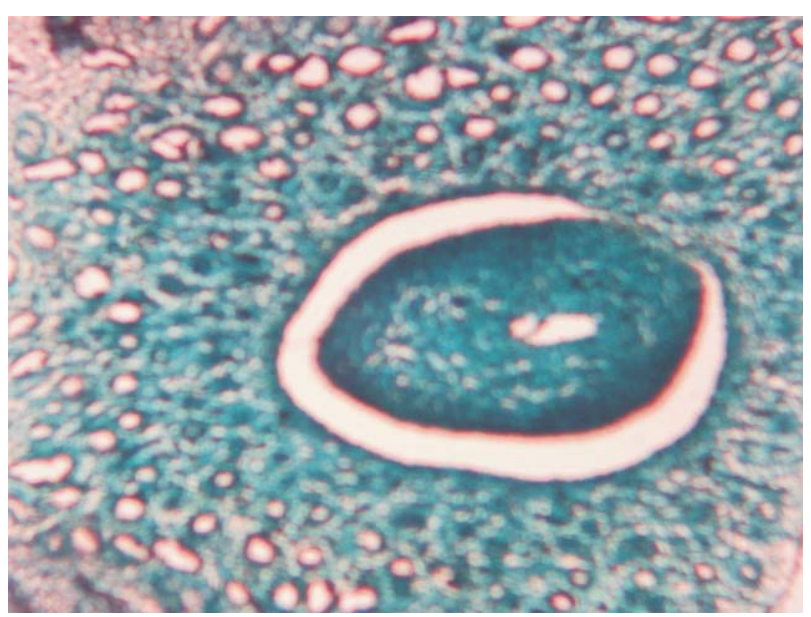

Figure 7. Nyamplung flower ovum

\section{B. Fruiting Session}

Nyamplung starts to produce fruits after pollinated by insects. One of these pollination vectors is beetle as illustrated by the Figure 8 . Fruiting session occurred between 1.5 and 2.5 months and showed some differences between locations. The fruiting sessions in the three locations of Jerowaru, Korleko, and North Batukliang were: 2.5 months (from May to August), 2 months (from June to August), and 1.5



Figure 8 . Nyamplung pollination by beetle 




Figure 9. Nyamplung fruiting season in Jerowaru

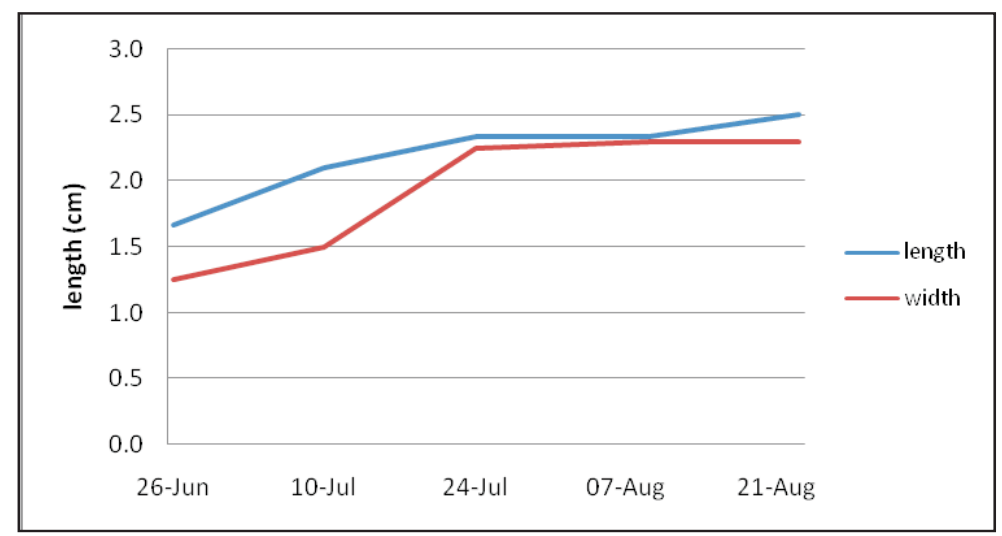

Figure 10. Nyamplung fruiting season in Korleko

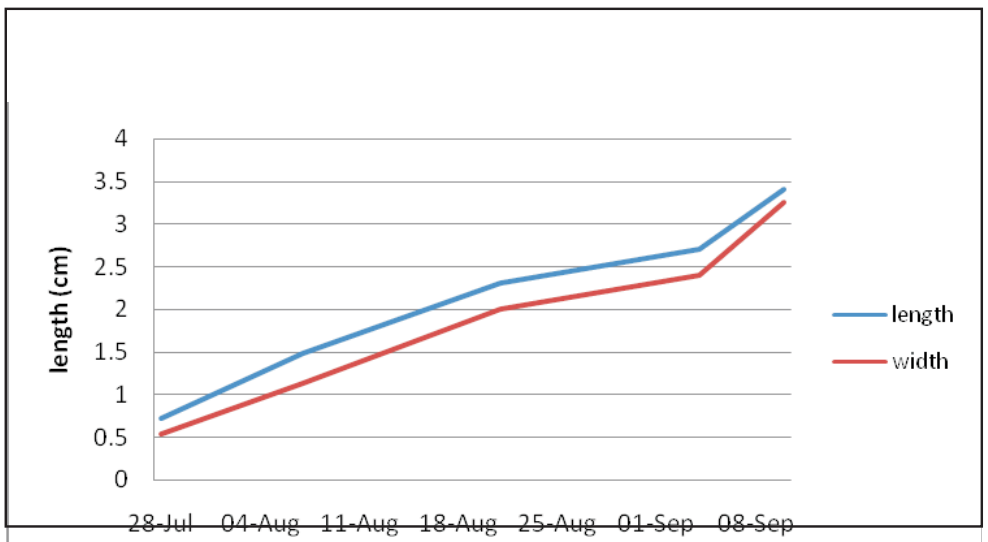

Figure 11. Nyamplung fruiting season in North Batukliang

Table 5. Variance analyses result of fruit length between individual fruits

\begin{tabular}{lrrrrr}
\hline & \multicolumn{1}{c}{ Sum of } & & & & \\
& Squares & Df & Mean Square & F & \multicolumn{1}{c}{ Sig. } \\
\hline Between Groups & 4.601 & 2 & 2.300 & 51.651 & $.000\left(^{*}\right)$ \\
Within Groups & 1.069 & 24 & .045 & & \\
\hline Total & 5.670 & 26 & & & \\
\hline
\end{tabular}


Table 6. Multiple comparison (LSD) results of fruit length between individual fruits from all sites

\begin{tabular}{|c|c|c|c|c|c|c|}
\hline \multirow{2}{*}{ (I) SITE } & \multirow{2}{*}{ (J) SITE } & \multirow{2}{*}{$\begin{array}{c}\text { Mean } \\
\text { Difference } \\
(\mathrm{I}-\mathrm{J})\end{array}$} & \multirow{2}{*}{ Std. Error } & \multirow{2}{*}{ Sig. } & \multicolumn{2}{|c|}{ 99\% Confidence Interval } \\
\hline & & & & & Lower Bound & Upper Bound \\
\hline \multirow[t]{2}{*}{1.00} & 2.00 & $.5000\left(^{*}\right)$ & .09948 & .000 & .2217 & .7783 \\
\hline & 3.00 & $-.5111\left(^{*}\right)$ & .09948 & .000 & -.7894 & -.2329 \\
\hline \multirow[t]{2}{*}{2.00} & 1.00 & $-.5000(*)$ & .09948 & .000 & -.7783 & -.2217 \\
\hline & 3.00 & $-1.0111\left(^{*}\right)$ & .09948 & .000 & -1.2894 & -.7329 \\
\hline \multirow[t]{2}{*}{3.00} & 1.00 & $.5111\left(^{*}\right)$ & .09948 & .000 & .2329 & .7894 \\
\hline & 2.00 & $1.0111\left(^{*}\right)$ & .09948 & .000 & .7329 & 1.2894 \\
\hline
\end{tabular}

*) The mean difference is significant at the 0.01 level.

Site $1.00=$ Jerowaru; Site $2.00=$ Korleko; Site $3.00=$ North Batukliang

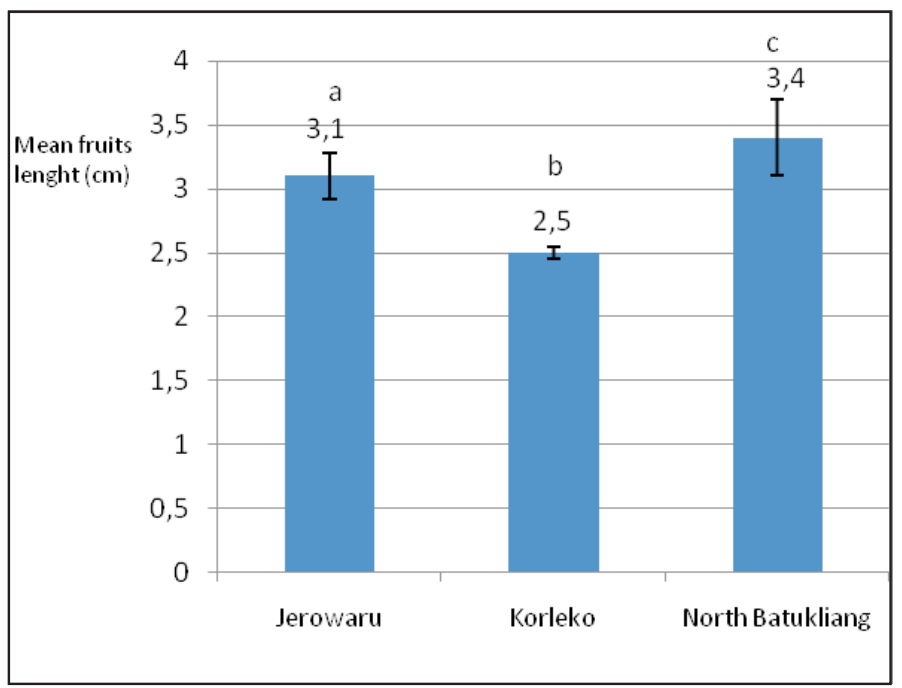

Figure 12. Nyamplung fruit length. The same letters on the histograms indicate no significant difference in the corresponding fruit length $(\varrho<0.01$ by LSD test)

months (from July to September) respectively. The fruiting sessions for each location are presented in Figure 9,10 and 11 respectively.

Nyamplung fruit length showed some differences. Analysis of variance (ANOVA) and further LSD test showed that the difference was found significantly on the length of fruit between the individual fruits and between locations (Tables 5 and 6). As showed by the Figure 12, the longest average fruit length was found in North Batukliang $(3.4 \mathrm{~cm})$ where as the shortest was found in Korleko $(2.5 \mathrm{~cm})$.

\section{Ripe Fruit, Seed Viability, and Fruit Harvesting Time}

The percentage of ripe fruits in Jerowaru, North Batukliang and Korleko were 32.78\%,
$36.45 \%$, and $40.29 \%$ respectively (Figure 13). Nyamplung trees in Korleko had the highest fruit production, where as the least one was in Jerowaru. Environmental and indigenous factors affected production as well as quality of the fruits. Field study indicated that many of young fruits were fall during the fruiting period, but it is difficult to understand which factors that had affected this phenomenon.

The competition of pollen among flowers in one tree was believed as the endogenous factor that affects fruit production (Lestari, 2010). The premature drop of flowers and fruits might be resulted by the competition for metabolism between vegetative and reproductive shoots. Abortion was seen as a trade-off between seed number and seed quality that permits the parent 


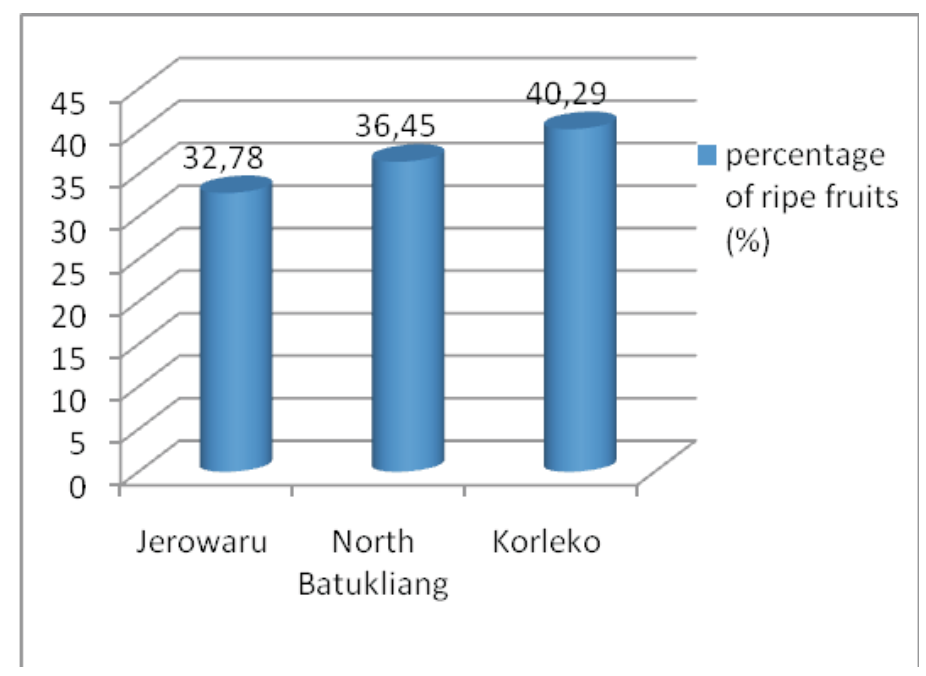

Figure 13. Percentage of ripe fruits in Jerowaru, North Batukliang, and Korleko

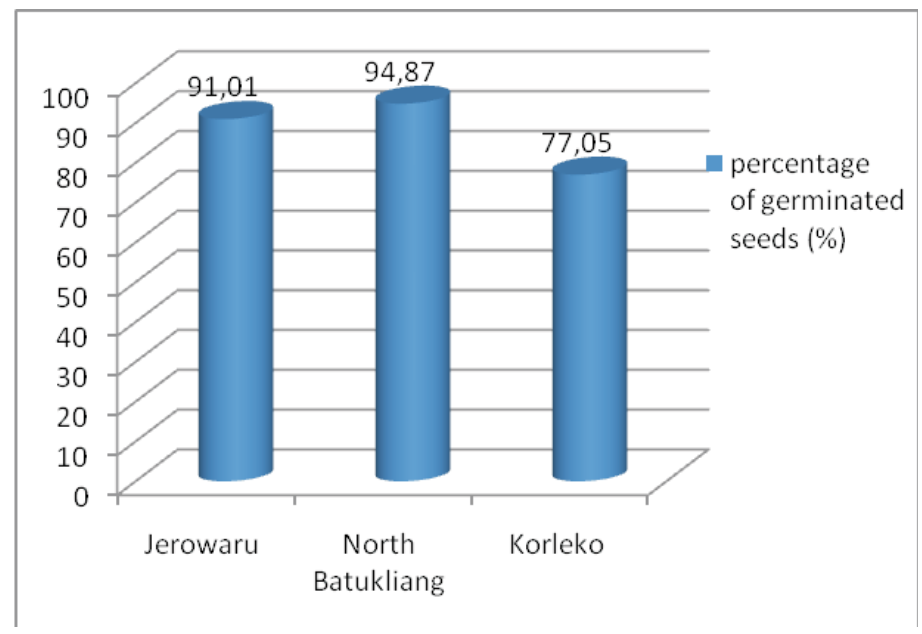

Figure 14. Germinated seed percentages in Jerowaru, North Batukliang, and Korleko

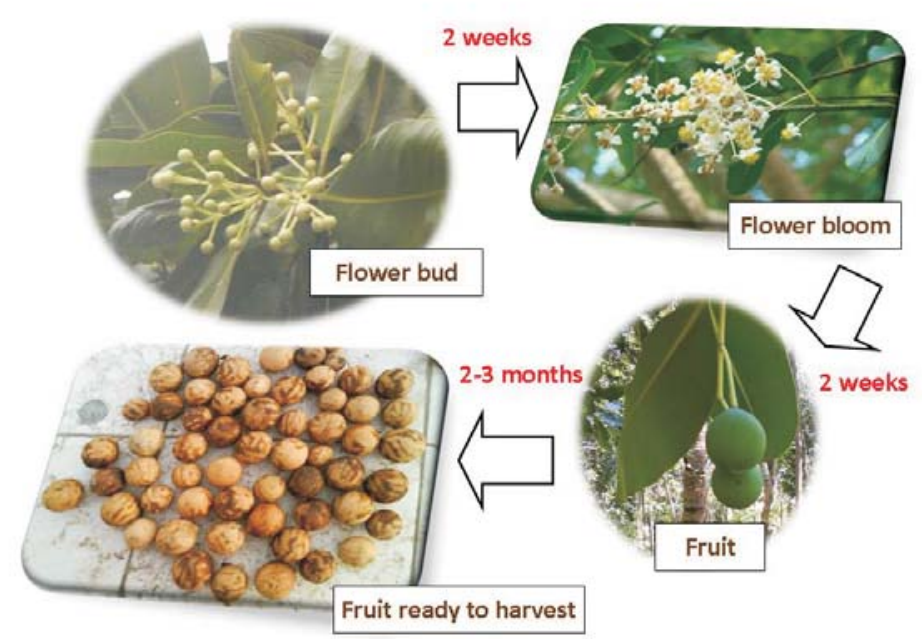

Figure 15. Nyamplung flower and fruit development scheme 
plant to match fruit production with available resources. Loss of flowers and fruits vary between species (Raghavendra, 1991). This study in Jerowaru indicated somewhat evidence that the strong wind was happened in a short period that caused many drops of young fruits in some trees.

Fruit quality is a critical issue for successful seed stocking and continuity of seedling production. Seed germination trials were done to know the viability seeds that were harvested from the study sites. Figure 14 shows the percentage of nyamplung germinated seeds of all sites. The highest percentage of germinated seed was found in seeds that were harvested from North Batukliang (94.87\%), while from Jerowaru and Korleko the percentages were $91.01 \%$ and $77.05 \%$ respectively.

It took 1.5 - 2.5 months for young nyamplung fruit to mature. The actual fruit harvesting time among the sites differed due to the difference of initial flowering time. Based on the observation, the mature nyamplung fruit was available on August in Jerowaru and Korleko, while in North Batukliang was on October. Nyamplung flower and fruit development scheme are presented in Figure 15.

\section{CONCLUSION}

Nyamplung has perfect flowers with both male and female organs in a single flower. The length of flowers ranges from 3.5 to $4.2 \mathrm{~cm}$. The longest flower was found in Jerowaru. The flowering session occurs within a month, although there were differences on when the season accurs in the three study sites. Higher rainfall tends to delay nyamplung flowering period.

Nyamplung fruit is globose with its length from 2.5 to 3.4 and the width from 2.3 to $3.3 \mathrm{~cm}$. The fruiting process occurred from 1.5 to 2.5 months. The mature fruits in Jerowaru and Korleko could be available in August, while in North Batukliang in October. Percentage of the ripe fruits in Jerowaru, North Batukliang and
Korleko were $32.78 \%, 36.45 \%$ and $40.29 \%$ respectively, while the geminated seed percentage were $91.01 \%, 94.87 \%$, and $77.05 \%$, respectively.

\section{REFERENCES}

Bustomi, S., T. Rostiwati, R. Sudradjat, B. Leksono, A.S. Kosasih, D. Syamsuwida, Y. Lisnawati, Y. Mile, D. Djaenudin, Mahfudz. and E. Rahman. 2008. Nyamplung (Calophyllum inophyllum L.): The Potential Biofuel Resource. FORDA. Jakarta.

Departemen Kehutanan. 2008. Nyamplung (Calophyllum inophyllum L.) Sumber Energi Biofuel yang Potensial. Pusat Informasi Kehutanan. Jakarta.

Friday, J.B., and D. Okano. 2006. Calophyllum inophyllum (kamani) Species Profiles for Pacific Island Agroforestry, Traditional Tree Initiative, Hawaii. Online publication on www.traditionaltree.org (accessed 28.05.2011).

Heyne, K. 1987. Tumbuhan Berguna Indonesia jilid 3, 1375-1378, Badan Litbang Kehutanan; Jakarta.

Lesica, P. and P.M. Kittelson. 2010. Precipitation and temperature are associated with advanced flowering phenology in a semiarid grassland. Journal of Arid Environments 74 (2010): 1013 - 1017.

Lestari, F. 2010. Karakteristik pembungaan tiga provenan dan empat lahan cendana. Jurnal Penelitian Hutan Tanaman No. 7 vol 2. Puslitbang Hutan Tanaman. Bogor.

Pallardy, S.G. 2008. Physiology of Woody Plants. Third Edition. Elsevier Inc. London.

Raghavendra, A.S. 1991. Physiology of Trees. John Wiley and Sons, Inc. USA.

Warnock, D. F., W.M. Randle, and O.M. Lindstrom. 1993. Photoperiod, Temperature, and Plant Age Interact to Affect Short-day Onion Cold Hardiness. Hortscience, Georgia. 